\title{
GAMBARAN KETERAMPILAN SOSIAL EMOSI ANAK AUTISM SPECTRUM DISORDER (ASD) DI SEKOLAH PAUD INKLUSI BUNDA GANESA
}

\author{
Aulia Rahmawati Dewi, Juhanaini, Aan Listiana \\ Universitas Pendidikan Indonesia, Jln. Setiabudhi no. 229 Bandung \\ e-mail: Aulirahmawati.dewi@upi.edu
}

\begin{abstract}
Abstack : The Description of Social Emotional Skills Children with Autism Spectrum Disorder (ASD) in Paud Inklusi Bunda Ganesha. Much research on emotional-social skills has been done; however, there is limited research on the emotional-social skills and stimulations for young children, especially those with Autism Spectrum Disorder (ASD). Therefore, the writer attempts to conduct research on ASD children focusing on their emotional-social skills. The problem in this research is formulated this way: "How are the emotional-social skills of children with Autism Spectrum Disorder in Bunda Ganesa Early Childhood Education School described?" The research adopted a descriptive method with the qualitative approach. Qualitative research was selected because this research emphasizes investigative efforts to (naturally) study the on-going phenomena in the finding of the emotional-social skills of children with ASD at Bunda Ganesa Early Childhood Education School. The research involved a four-year-old boy diagnosed with ASD. The research was conducted from October 1 - November 7, 2014. The findings show that children with ASD experience some obstacles, which support the existing theories, where children with ASD have difficulties in communicating, tend to avoid eye contact (not focused), and have difficulties in using gestures to communicate. In addition, children with ASD are inclined to enjoy being alone and become disinterested in playing with their friends. In the field, it is not impossible that the writer finds obstacles and problems during the writing of this undergraduate thesis. Teachers and schools are recommended to pay more attention and help improve the development of children with ASD because children have much potential to develop.
\end{abstract}

Keywords: social skills, emotional skills, autism spectrum disorder (ASD)

\begin{abstract}
Abstrak : Gambaran Keterampilan Sosial Emosi Anak Autism Spectrum Disorder (ASD) di Sekolah PAUD Inklusi Bunda Ganesa. Berbagai Penelitian Keterampilan Sosial emosional telah banyak dilakukan, namun dalam penjelasan tentang keterampilan sosial emosional serta stimulasi bagi anak usia dini masih sangat terbatas terutama bagi anak ASD. Untuk itu penulis mencoba meneliti anak ASD mengenai keterampilan sosial emosinya. Rumusan masalah dalam penelitian ini adalah Bagaimana Gambaran Keterampilan Sosial Emosi Anak Autism Spectrum Disorder di Sekolah PAUD Inklusi Bunda Ganesa. Metode yang digunakan dalam penelitian ini adalah metode deskriptif dengan pendekatan kualitatif. Penelitian kualitatif atau kajian kualitatif digunakan dalam penelitian ini karena penelitian ini menekankan pada upaya investigatif untuk mengkaji secara ( alamiah), fenomena yang tengah terjadi dalam mengetahui keterampilan sosial emosi anak Autism Spectrum Disorder (ASD) di sekolah PAUD Inklusi Bunda Ganesa. Subjek penelitian yang terlibat dalam penelitian ini adalah Anak laki-laki yang berusia 4 tahun yang di diagnosa mengalami Autism Spectrum Disorder (ASD). Pelaksanaan dimulai dari tanggal 1 Oktober -7 November 2014. Hasil Penelitian yang ditemukan anak ASD ini mengalami beberapa hambatan yang sesuai dengan teori
\end{abstract}


yang sudah ada, dimana anak yang mengalami ASD akan mengalami kesulitan berkomunikasi, ia akan menghindari kontak mata (tidak fokus), kesulitan dalam menggunakan sikap tubuh untuk berkomunikasi. Dan cenderung anak yang mengalami ASD ini lebih senang untuk menyendiri dan tidak tertarik untuk bermain bersama teman-temannya. Dalam pelaksanaan di lapangan penulis tidak menutup kemungkinan penulis menemui hambatan dan kendala-kendala yang muncul pada saat melakukan penulisan skripsi ini. Rekomendasi untuk Orangtua, Lembaga sekolah sebaiknya lebih memperhatikan dan membantu meningkatkan perkembangan anak ASD. Karna ada beberapa perkembangan anak yang dapat terus dimotivasi agar berkembang.

Kata Kunci : keterampilan sosial, keterampilan emosi, autism spectrum disorder (ASD)

\section{Autism}

merupakan

perkembangan, seperti

gangguan

komunikasi,

interaksi sosisal, dan perilaku. Untuk dapat beradaptasi dengan lingkungan sekitarnya tidaklah mudah karna umumnya anak yang mengalami autism sering dijauhi oleh teman-temannya. Memang anak yang mengalami autism ini perlu penanganan khusus yang berbeda dangan anak normal lainnya, namun tak sepantasnya kita meremehkan mereka.

Keterampilan merupakan salah satu aspek yang mendukung atau menunjang dalam proses interaksi. Keterampilan sosial merupakan keterampilan yang berkaitan dengan hubungan atau interaksi antara individu dengan lainnya. Keterampilan sosial merupakan keterampilan yang erat hubungannya dengan kehidupan masyarakat. Keterampilan sosial anak merupakan cara anak dalam melakukan interaksi, baik dalam hal bertingkah laku maupun dalam hal berkomunikasi dengan orang lain dan lingkungan sekitarnya.

Pada keterampilan sosial pada umumnya anak autism mengacuhkan suara, penglihatan ataupun kejadian yang melibatkan mereka. Jika ada reaksi biasanya reaksi ini tidak sesuai dengan situasi atau malahan tidak ada reaksi sama sekali. Mereka menghindari atau tidak merespon terhadap kontak sosial (pandangan mata, sentuhan kasih sayang, bermain dengan anak lain dan sebagainya) yang di kemukakan Yuwono (2012: hlm 79).

Berdasarkan penjelasan diatas jumlah anak autism membutuhkan berbagai aspek terkait yang dapat dikembangkan dalam sistem pendidikan, dukungan dari keluarga dan lingkungan sekitar agar dapat menyalurkan perkembangan sosial emosi yang sesuai pada umumnya pada anak-anak autism. Pada penelitian ini peneliti akan meneliti gambaran keterampilan sosial emosi anak ASD (Autism Spectrum Disorder) usia dini di sekolah inklusi PAUD Bunda Ganesa. Apakah mengalami kemajuan dan dapatkah anak tersebut beradaptasi dengan teman-teman, dapat berinteraksi dengan temannya, menunjukan sikap simpati dan empati, dan mengungkapkan dalam keterampilan emosinya. Sebagaimana kita tahu keterampilan sosial emosi anak perlu mendapat perhatian penting dalam pengembangan stimulasi emosi anak usia dini. Oleh karena itu penulis tertarik untuk meneliti keterampilan sosial emosi anak Autism Spectrum Disorder (ASD) di Sekolah PAUD Bunda Ganesa.

\section{METODE}

Jenis Penelitian yang digunakan dalam penelitian ini adalah studi kasus. Dalam pelaksanaanya, pelaku riset berpegang pada 
suatu asumsi teoritis tentang suatu fokus riset, yang dirumuskan sendiri sebelum berangkat mengumpulkan data, asumsi teoritis ini bisa saja berubah setelah data dikumpulkan. Oleh sebab itu pengumpulan data itu tidak dapat dilakukan hanya satu atau dua kali, melainkan berkali-kali, maka bisa terjadi perubahan terhadap asumsi teoritis yang dirumuskan oleh pelaku riset itu terjadi berkali-kali pula. Namun karena keterbatsan waktu peneliti maka penelitian kualitiatif yang dilakukan di PAUD Bunda Ganesa kota Bandung ini dilakukan selama satu bulan lebih sejak bulan OktoberNovember yang dalam pelaksanaannya peneliti tidak sepenuhnya berada dilapangan Penelitian berlangsung terjadi .

Teknik pengumpulan data dalam penelitian ini menggunakan metode observasi, wawancara, studi dokumentasi dan catatan lapangan.

\section{HASIL DAN PEMBAHASAN}

Berdasarkan hasil wawancara dan Observasi, hal tersebut dapat dicermati menurut data yang telah diperoleh Budi mengenai keterampilan sosial emosi, bahwa Budi dapat memperkenalkan diri sendiri meskipun pada awalnya Budi belum dapat berinteraksi dan menerima kehadiran orang yang baru dikenalnya dan mengekspresikan diri menerima kehadiran pada saat berkenalan, begitu pun dengan teman- teman di lingkungan sekolahnya, ia belum dapat berbaur dan bermain bersama. Karena pada umumnya anak yang menginjak usia pra sekolah seharusnya anak mulai dapat memilih dan mempunyai teman yang sesuai, mempunyai teman dekat, dan menghindari teman-teman yang tidak di sukai temannya atau yang membahayak dirinya Disinilah Budi belum dapat memahami situasi yang ada sekitarnya. Budi cenderung tidak mempedulikan lingkungan sekitar meskipun pada saat bermain apabila ada temannya yang merebut mainan dari dirinya ia tidak mempedulikan dan memilih untuk bermain mainan yang lain, disinilah terlihat bahwa keterampilan sosial emosi Budi tidak terlihat dan tidak muncul seperti halnya anak pada umumnya, Budi lebih banyak diam apabila teman-temannya sedang melakukan kegiatan bermain bersama-sama dan tidak mau ikut serta untuk bergabung bermain, seakan ia tidak tertarik untuk bermain bersama temannya dan memilih untuk bermain sendiri.

Menurut informan Psikolog di sekolah, terlihat bahwa keterampilan sosial emosi terdapat dua faktor yang dapat mempengaruhi keterampilan sosial pada anak ASD yaitu faktor internal dan faktor eksteranal, faktor internalnya yaitu faktorfaktor yang terdiri pada anak tersebut. Memang tidak dapat dipungkiri inilah hambatan yang terjadi pada anak yang mengalami ASD sulitnya bagi Budi untuk menerima kehadiran orang baru dan yang ia rasa tidak nyaman bersamanya. Faktor eksternal sendiri yaitu faktor-faktor yang mempengaruhi di peroleh anak dari luar dirinya sendiri seperti faktor keluarga, faktor Gizi, budaya, teman bermain dan teman sekolahnya. Lingkungan keluarga sangat berpengaruh dalam membentuk kepribadian anak dan sikap, kebiasaan keluarga dalam mengasuh anak dan mendidik anak, karna keluarga lah proses dalam dalam pertumbuhan dan perkembangan keterampilan sosial anaknya.

Untuk mencapai kematangan sosialnya, anak harus belajar tentang caracara menyesuaikan diri dengan orang lain. Kemampuan ini diperoleh anak melalui kesempatan atau pengalaman bergaul dengan orang-orang dilingkungannya, baik orang tua, saudara, teman sebaya ataupun 
orang dewasa. Anak ASD (Budi) memiliki perbedaan keterampilan sosial emosi anak pada umumnya, dimana anak-anak yang di diagnosis mengalami autism menunjukan hambatan di interaksi sosial, komunikasi, dan permainan imajinasi sebelum mereka menginjak usia tiga tahun.

Dari hasil observasi yang dilakukan oleh peneliti ternyata bahwa anak ASD ini mengalami beberapa hambatan yang sesuai dengan teori yang sudah ada, dimana anak yang mengalami ASD akan mengalami kesulitan dalam berkomunikasi, ia akan menghidar kontak mata dengan seseorang yang mengajaknya berbicara (tidak fokus/ mengalihkan pandangan), kesulitan dalam menggunakan sikap tubuh untuk berkomunikasi. Cenderung anak yang mengalami ASD ini lebih senang untuk menyendiri dan tidak tertarik untuk bermain bersama teman-temannya.

Dalam aspek sikap simpati dan empati dengan temannya pun aga sulit, karna mereka sendiri biasanya tidak dapat memahami dengan apa yang harus mereka lakukan, apakah yang mereka lakukan itu baik ataupun buruk, kerap kali anak yang mengalami ASD juga sangat kesulitan dalam mengekspresikan wajahnya ketika mereka berkomunikasi dengan orang lain mereka biasanya memasang mimik muka yang dingin dan tidak memperhatikan wajah orang yang sedang mengajaknya bicara.

Anak ASD juga biasanya tidak paham dengan penempatan emosi yang sesuai misalkan saja ia tidak ikut gembira ketika ada teman yang sedang gembira, atau sedih ketika ada teman yang sedang sedih dan tidak tertawa saat teman sedang tertawa. Dalam pengulangan kata-kata yang dilakukan anak ASD tanpa mengandung arti ini kerap dilakukannya, seperti halnya ia tidak mau melakukan aktivitas yang sedang ia lakukan. Karena sebagaimana kita tahu bahwa anak Autism mengalami gangguan perkembangan yang kompleks sehingga mereka juga disebut mengalami gangguan pervasif. Peeters (2004 : hlm 4) mengartikan bahwa pervasif yaitu menderita kerusakan jauh di dalam meliputi keseluruhan dirinya. Istilah pervasif juga dilandasi oleh gangguan perkembangan yang di perlihatkan oleh anak Autistic Spectrum Disorder.

Keterampilan sosial emosi yang dimiliki subjek Budi Hal ini diperkuat dengan hasil penelitian yang dilakukan pada saat observasi berlangsung anak yang mengalami Autism Spectrum Disorder (ASD), ternyata memiliki kesamaan pada hambatan yang dialami oleh anak ASD dengan teori yang ada. Agar lebih jelas mengenai gambaran keterampilan sosial emosi anak ASD dapat dilihat secara kongkrit hasil penelitian yang telah dilakukan.

Berdasarkan hasil penelitian subjek Budi memiliki keterampilan sosial emosi yang tidak sesuai dengan usia seharusnya, meskipun ada memang beberapa keterampilan sosial yang dapat dilakukan oleh Budi namun dalam hubungan sosial Budi dengan teman- teman sebayanya masih belum dapat dilakukannya.

\section{SIMPULAN}

Berdasarkan hasil penelitian dapat ditarik kesimpulan bahwa keterampilan sosial anak Autism Spectrum Disorder pada subjek penelitian di PAUD Bunda Ganesa sebagai berikut :

1. Keterampilan menjalin persahabatan pada subjek penelitian masih harus membutuhkan pendampingan. Kondisi ini dikarenakan ia tidak mudah untuk dapat membuka diri dan percaya pada orang lain dan lebih cenderung ia lebih memilih asik bermain sendiri ketimbang 
untuk bergabung dengan teman-teman yang lainnya. Selain itu ia masih memiliki sifat kelekatan pada satu orang saja, ketika berada di sekolah ia hanya merasa nyaman hanya dengan guru pendamping (helper) saja, rasa percaya dirinya akan timbul ketika ia bersama guru pendampingnya.

2. Keterampilan berperan dalam kelompok pada subjek penelitian masih harus membutuhkan bimbingan, ia masih bersifat ikut-ikutan, terkadang tidak sabar untuk menunggu giliran dan belum dapat mengikuti aturan yang ada pada kelompok. Kondisi seperti ini dikarenakan rasa percaya diri anak yang belum timbul ketika harus bekerjasama dengan teman satu kelompoknya sehingga ia masih perlu terus di motivasi dan diingatkan untuk menumbuhkan rasa percaya dirinya.

3. Keterampilan bersopan santun pada subjek penelitian sudah dapat karena dilatihnya dan seringnya ia melakukan perbuatan yang positif ia seperti mencium tangan pada guru, mengucapkan salam, berbicara tidak berteriak, dan secara bertahap masih terus dimotivasi untuk dapat menyapa orang apabila berpaspasan ia bertemu dengan orang lain.

Keterampilan kemadirian subjek penelitian cukup baik, karena ia sudah dapat berpisah dengan kedua orangtua nya tanpa menangis dan sudah menjadi suatu kebiasaan yang rutin anak dapat membuka sepatu dan tas lalu menyimpan ke dalam tempatnnya, anak sudah dapat mengungkapkan dan pergi ke toilet apabila ingin buang air kecil maupun buang air besar. Meskipun begitu mereka tetap membutuhkan motivasi dan latihan dari orang sekelilingnya untuk menumbuhkannya rasa percaya diri.

\section{DAFTAR PUSTAKA}

Peeters, Theo. (2009). Panduan Autisme Terlengkap, Jakarta: Dian Rakyat.

Yuwono. (2009). Memahami Anak Autistik. Bandung: ALFABETA. 